\title{
FLIGHT 93 NATIONAL MEMORIAL REFORESTATION PROJECT: SURVIVAL AND GROWTH OF NATIVE WOODY PLANTS ESTABLISHED ON RECLAIMED MINELAND ${ }^{1}$
}

\author{
M.C. Tyree ${ }^{2}$, J.L. Larkin, S.D. Eggerud, P.N. Angel, M.E. French, and C.D. Barton
}

\begin{abstract}
The Flight 93 National Memorial is located in Somerset Co., near Shanksville, PA. The site was surfaced mined and much of the 890 ha of reclaimed land was re-contoured and seeded in the mid 1990's. Starting in the spring 2012, the National Park Service, Office of Surface Mining Reclamation and Enforcement, and others have worked to reforest sections of the total area using native woody trees and shrubs. Each spring for the past six years (2012-17) over 500 volunteers planted a new section, which we have defined as a "Phase," of the National Memorial. The Flight 93 National Memorial Reforestation Project was established to evaluate reforestation success and provide data to drive future management decisions. Specifically, this work aims to: O1) Determine abundance and percent stocking for each of the 34 native, woody species planted across the six Phases; O2) evaluate growth of woody plants; and O3) describe level of competing vegetation across each phase. Two hundred and sixteen permanent, fixed radius plots were established randomly throughout the six planting phases with the goal to maintain a minimum target sampling intensity of $10 \%$. Percent stocking, growth, and deer browse data were collected for all planted trees and shrubs within the sampling plots. Competition data was collected using $1 \mathrm{~m}^{2}$ rectangular sub-plots nested within whole-plot. Of the 102,393 trees and shrubs $\left(1,792\right.$ trees ha $\left.{ }^{-1}\right)$ planted at The Flight 93 National Memorial we sampled a total of 8,673 individual trees and shrubs. Total percent stocking across all six planting Phases was $74.5 \%$ ranging from $40-121 \%$ within individual Phases, with natural regeneration driving stocking levels above $100 \%$ in one of the planting phases. Greatest plant growth was observed in the conifer species with white pine and pitch pine driving this pattern. Among the deciduous trees we observed the greatest growth among the early successional species such as quaking aspen and black locust. Overall, $88 \%$ of all plants showed no sign of deer browse, however, this rate is expected to increase as the plants emerge above the competing vegetation. Competing vegetation across all six planting phases was dominated by grasses, sedges, and herbaceous dicots and constitutes the largest limitation to woody plant establishment.
\end{abstract}

Additional Key Words: competing vegetation, deer browse, surface-mine reclamation

\footnotetext{
${ }^{1}$ Paper presented at 2017 American Society of Mining and Reclamation and Appalachian Regional Reforestation Initiative (ARRI) Joint Conference. Morgantown, WV. April 10, 2017.

${ }^{2}$ Michael Tyree is an Assistant Professor, Department of Biology, Indiana University of Pennsylvania, Indiana, PA 15705; Jeffrey Larkin is a Professor, Department of Biology; Scott Eggerud and Patrick Angel are with the Office of Surface Mining Reclamation and Enforcement; USDI; Michael French with Green Forests Work; and Christopher Barton is a Professor, Watershed Management, University of Kentucky, Lexington, KY 40506.
}

Journal American Society of Mining and Reclamation, 2018 Volume 7, Issue 2 pp 35-60

DOI: http://dx.doi.org/10.21000/JASMR18020035 


\section{$\underline{\text { Introduction }}$}

The Flight 93 National Memorial located in Somerset Co., near Shanksville, PA, was created to commemorate the 40 passengers and crew members of United Airlines Flight 93, who courageously gave their lives to save others during the terrorist attacks on September 11, 2001. Passengers and the crew of Flight 93 forced the terrorists to crash the plane on a reclaimed surface mine, thwarting an attack on our nation's capital. The memorial site was officially dedicated and opened to the public on September 10, 2011. The site was surface mined from the 1950's until the mid-1990's (NPS 2013). Upon completion much of the 890 ha of reclaimed surface mine land was re-contoured and seeded with a mix of grasses, herbaceous plants, and planted with exotic conifers and hardwoods to prevent erosion and provide wildlife habitat in accordance to the federal Surface Mine Reclamation Act of 1977. The site continued to be deep mined until 2002.

Starting in spring 2012, the National Park Service and Office of Surface Mining Reclamation and Enforcement teamed with others to reforest sections of the total area using native woody trees and shrubs following methods outlined by the Appalachian Regional Reforestation Initiative (ARRI) for reforesting legacy mine lands (ARRI, 2012; Burger et al., 2017). Each spring for the past six years (2012-17) a new section (Phase) of the site was planted with native trees and shrubs by over 500 volunteers. These plantings represent a significant investment of funds, time, and resources; and as such, the success of this effort is being evaluated. The Flight 93 Reforestation Project has the advantage of being highly visible to the public, which provides the potential to serve as a demonstration area as well as contribute to other outreach efforts.

Across the National Memorial there were over 34 woody species selected for planting. Species selection was constrained by availability of bare-root planting stock, but was intended to include tree and wildlife species that are native to Pennsylvania. The selection included popular conifer species common to reforested mine-land sites such as white, red, and pitch pine, however, there were less common species included such as eastern hemlock. Among deciduous species selected there were a mix of early successional, fast growing trees such as black locust and aspen planted as well as mid successional, hard mast producing species such as oaks and hickory. This site also included over 5,000 blight-resistant American chestnut hybrid backcrosses donated by the American chestnut foundation. Due to the vast and diverse selection of woody species and the 
high visibility of this site, these plantings offer a tremendous opportunity to compare establishment success and forest development over the long term.

The purpose of The Flight 93 National Memorial Reforestation Monitoring Project was to survey all planting phases (Phases I-VI) to evaluate total and relative stocking, growth, health, and level of competing vegetation. This work was organized by three specific objectives. Due to differences in planting dates, each Phase was evaluated independently. Specifically, we aimed to:

01: Determine abundance, percent stocking, and dispersion for each planted species in each of the six (I-VI) planting phases. In addition, comparisons between this year's 2017 inventory will be compared to the 2015 data;

O2: Evaluate plant growth and level of deer browse for each woody species planted in each of the six (I-VI) planting phases; and

O3: Describe competing vegetation and determine if it is impacting planting success. Overall site trends will be evaluated to determine how the Flight 93 National Memorial is progressing over the six years of active reforestation that has taken place. Assessment of available growing space and competing vegetation for each of the six planting phases.

\section{Methods}

\section{Site Description and History}

The Flight 93 National Memorial is located in Somerset Co., near Shanksville, PA (40.058, 78.905; Fig. 1). It is situated on approximately 890 hectares (2,200 ac) of reclaimed surface mined land. The 30-year (1981-2010) average annual high and low temperature is $14.5^{\circ} \mathrm{C}$ and $2.0^{\circ} \mathrm{C}$. Greatest average monthly high $\left(26.3^{\circ} \mathrm{C}\right)$ and low $\left(-9.6^{\circ} \mathrm{C}\right)$ temperatures occur in July and January, respectively (U.S.Climate_Data 2015b). The site receives $137.7 \mathrm{~cm}$ (54.2 in) of rainfall and $226 \mathrm{~cm}$ (89 in) of snowfall annually (U.S.Climate_Data 2015a).

Reforestation began in 2012 with Phase I and each spring another planting phase was added with Phases I-VI totaling 57.1 ha (Table 1; Fig. 1). A total of 102,393 woody trees and shrubs representing 34 native species were planted in ripped soil between 2012 and 2017 (Table 2). Each

year the absolute number of trees and shrubs planted varied widely (11,600 to 22,000), however when relativized by the planting area (Table 1), the relative number of woody plants (plants per hectare) ranged from 1,593 to 1,968 plants $\mathrm{ha}^{-1}$. 
Journal American Society of Mining and Reclamation, 2018 Vol.7, No.2

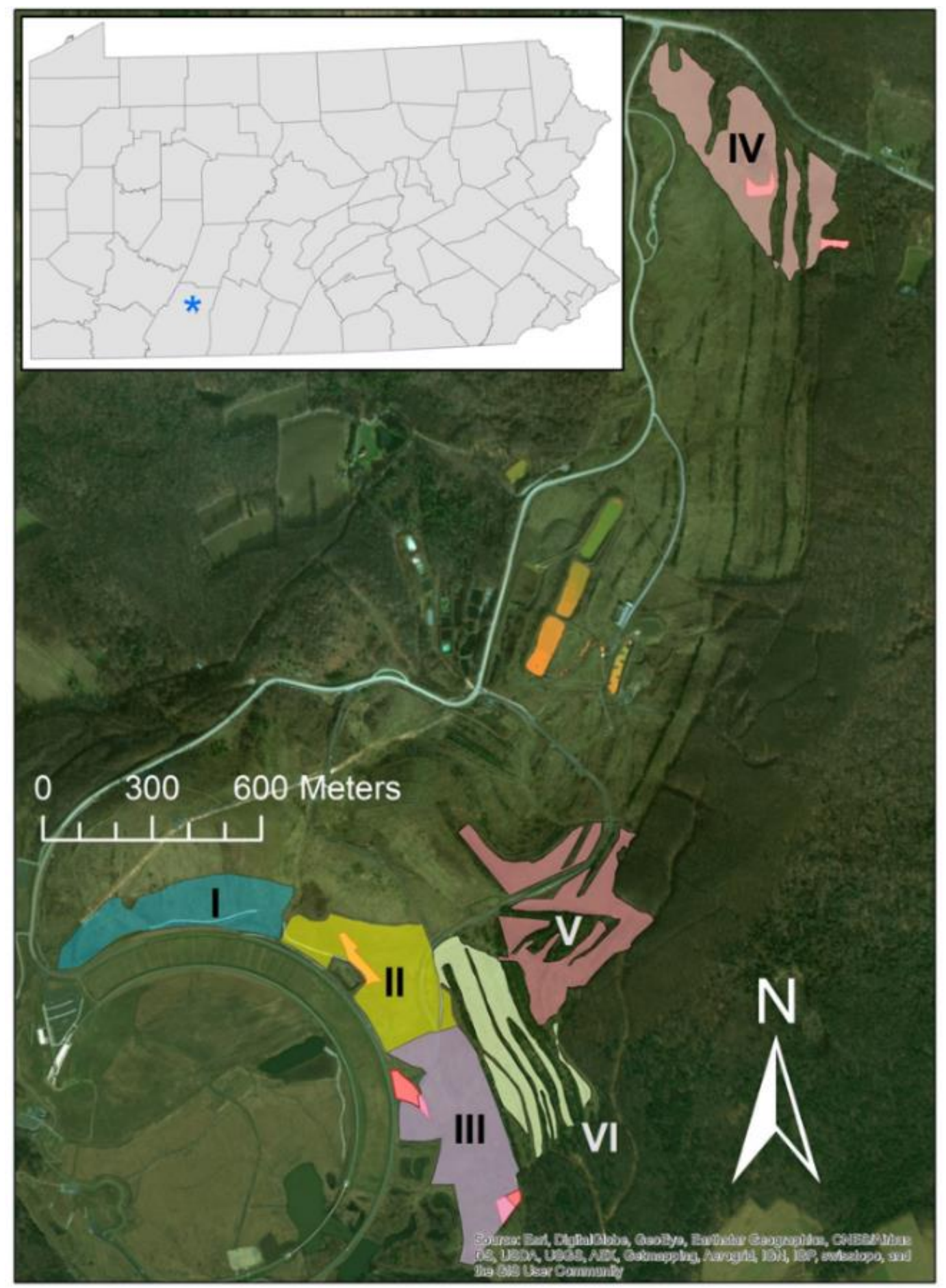

Figure 1. Map of Flight 93 National Memorial located near Shanksville, PA. Colored polygons represent reforestation planting phases (I-VI). Small, red polygons represent special planting zones within Phases II-IV. Inset map shows Somerset County, PA with blue asterisk representing Memorial location. Aerial photo was taken from ESRI ArcMap Basemap layer. 
Table 1. Summary statistics for Phases I-VI of The Flight 93 National Monument Reforestation Project. Each plot was 0.04 ha in size for Phases I-V and 0.01 ha for Phase VI.

\begin{tabular}{|r|r|r|r|r|}
\hline Phase & Yr. planted & Adj. area (ha) & No. of plots & \% sample \\
\hline I & 2012 & 7.68 & 28 & $14.9 \%$ \\
II & 2013 & 8.97 & 29 & $13.2 \%$ \\
III & 2014 & 11.77 & 30 & $10.4 \%$ \\
IV & 2015 & 11.18 & 30 & $11.0 \%$ \\
V & 2016 & 10.26 & 29 & $11.5 \%$ \\
VI & 2017 & 7.28 & 70 & $10.9 \%$ \\
\hline Total & & $\mathbf{5 7 . 1 4}$ & $\mathbf{2 1 6}$ & $\mathbf{1 1 . 8 \%}$ \\
\hline
\end{tabular}

\section{$\underline{\text { Plot Establishment }}$}

The perimeter of each planting phase was captured using a handheld GPS unit (Garmin GPSMAP 64S, Garmin Ltd., Olathe, KS). Spatial analysis software (ArcGIS 10.3, ESRI, Redlands, CA) was used to establish random, permanent plots using the following constraints:

$i$. no two plots could be within $30 \mathrm{~m}(100 \mathrm{ft})$ of each other;

ii. the entire plot must fall within the planting area; and

iii. each phase must have a minimum of $10 \%$ sampling.

Sampling plots were established in the field using a Trimble Juno T41 (Trimble Navigation Limited, Sunnyvale, CA) to locate and mark the plot center. Plot center was marked by driving a $30 \mathrm{~cm}$ (1 ft) piece of rebar into the ground (flush with soil surface). Rebar was left in the field so permanent sampling plots could be relocated for future sampling using known coordinates and a metal detector.

Phases I thru V, used 0.04 ha, fixed radius (circular) plots, which totaled approximately 30 plots per planting phase (Table 1). However due to the shape of Phase VI, we could not use 0.04 ha plots without violating the rules outlined above. As a result, we established seventy 0.01 ha plots throughout the planting phase, which allowed us to meet our plot criteria (Table 1). Each sampling plot was 0.04 ha $(0.10 \mathrm{ac})$ using an $11.4 \mathrm{~m}(37.2 \mathrm{ft})$ fixed radius. Within each plot, four $1 \mathrm{~m}^{2}$ subplots were nested $6.1 \mathrm{~m}(20 \mathrm{ft})$ to the nearest edge in each cardinal direction. Phase VI utilized 0.01 ha $(0.025 \mathrm{ac})$ circular plots using a $6 \mathrm{~m}$ fixed radius. Two $1 \mathrm{~m}^{2}$ subplots were nested $3 \mathrm{~m}$ to the nearest edge in the north and south direction. Phases I-IV were established in the 2015 inventory, however, phases V and VI were established in 2017 using the same criteria listed above. 


\section{Whole-plot data collection}

Prior to plot measurements, a single plot photograph was taken from the south subplot or $6 \mathrm{~m}$ away from plot center facing north with a field technician holding the height pole over plot center. Photographs will be used for visual comparisons throughout forest development. All planted trees and shrubs found within the sampling plot were measured. Volunteers (seedlings dispersed on their own) and existing sprouts were also measured. For each plant: species, ground-line diameter of dominant stem $\left(D_{\text {Basal }} ; \mathrm{mm}\right)$, height of dominant stem $(H t ; \mathrm{cm})$, diameter at $1.38 \mathrm{~m}$ height of dominant stem ( $\mathrm{DBH}$; only when plant was large enough), and estimation of level of deer browse was recorded. Deer browse was evaluated and each plant assigned a Browse Index (BI) value between $0-3$, where 0 indicated no browse and 1, 2, and 3 represented light ( $<1 / 3$ stems browsed), moderate (1/3-2/3 stems browsed), and heavy (>2/3 stems browsed) deer browse, respectively.

Total percent stocking (Obj. 1) was calculated by comparing number of planted (expected) trees and shrubs (Table 2) relativized on a per hectare basis using the area of each Phase (Table 1) and the number of measured (observed) plants by each planting phase and species. We expressed this relationship as a percent stocking rather than survival as it was difficult to differentiate planted trees from naturally regenerating trees in our older (5 years) planting phases and we felt this was a better reflection of what was currently growing across the site. As a result, our stocking estimates could potentially exceed $100 \%$, which would represent natural regeneration. Phases I-IV were also measured in 2015 which allowed for the calculation of percent change $(\% \Delta)$ in stocking between our 2015 and 2017 inventories. Finally, we estimated percent dispersion for each species by summing the number of plots each species was observed divided by total number of plots in each phase.

Plant growth and deer browse (Obj. 2) were determined using whole-plot data. Average and maximum plant height (Ht.) was calculated for each species by planting Phase. For Phases I-IV data was collected in 2015 and 2017 and we used the average height (A. Ht.) of each species by phase by year to calculate a growth rate (GRate; $\left.\mathrm{cm} \mathrm{yr}^{-1}\right)$. Finally, we evaluated the percentage of plants that fell into one of four Deer Browse Index categories (0-3) to evaluate which species were most susceptible to damage. 
Table 2. Absolute abundance (total number) of woody trees and shrubs planted across Phases I-VI of The Flight 93 National Monument Reforestation Project. Planting for each phase took place in the second half of April (I - IV) or first half of May (V \& VI) each year.

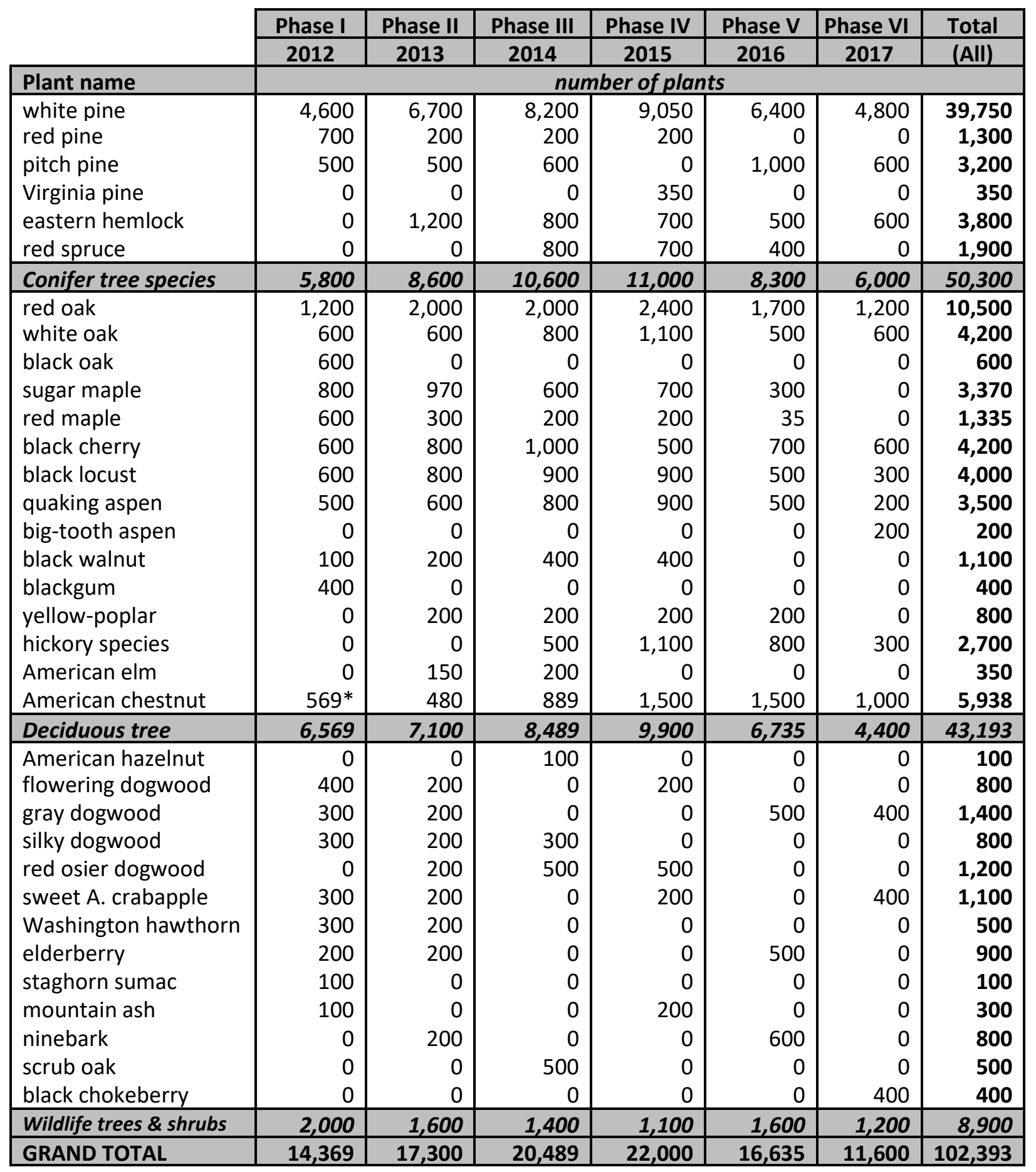

* TACF donated an additional 494 plants that were planted in April 2014. 


\section{$\underline{\text { Sub-plot data collection }}$}

Nested subplots were used to determine competing vegetation (Obj. 3) for each subplot nested within the sampling plot. Percent cover was estimated to the nearest 5\% from the following categories: bare soil, rock, coarse woody debris, grass/sedge, fern, herbaceous dicot (forb), Rubus spp., woody vegetation, and other. Data from all nested subplots were averaged to represent the sampling plot prior to analysis. Data was presented as total percent occupancy for each phase and as total available growing space (rock, water, were removed) and percentages were recalculated to reflect percent occupancy of available growing space by year since planting. Plot-level data was averaged and variance calculated as standard error for each phase.

\section{Data Analysis}

Each Phase was analyzed independently and treated as a separate experiment since time from planting was separated by one year for each phase. Sampling, data analysis, and reporting were performed identically for each phase. In addition, site-wide comparisons (all planting phases) were made for percent stocking, and treatment differences were tested using Analysis of Variance (ANOVA). These comparisons should be interpreted with caution as there are a variety of factors (planting conditions, timing of planting, age of plants, quality of nursery stock, etc.) that could influence survival of individual species. Statistical Analyses were performed by Analysis of Variance using a general linear model (GLM) in SAS University. Treatment separation procedures were performed using the PDIFF option within the LSMEANS statement.

\section{$\underline{\text { Results and Discussion }}$}

\section{Objective 1. Abundance and percent stocking}

A total of 102,393 trees were planted from 2012 thru 2017 within the six planting phases at The Flight 93 National Memorial (Table 2). This number is equivalent to 1,792 trees planted per hectare (Fig. 2; dashed line). We calculated percent stocking, which also includes plants that seeded naturally (volunteers) or sprouted from existing vegetation. Across all six planting Phases total percent stocking was $74.5 \%$, however, within individual planting Phases it ranged from 40 to greater than $100 \%$ with Phase V showing the greatest stocking due to a large number of plants that naturally regenerated and Phase III showed the least (Fig. 2). These stocking values are consistent with the prescribed planting rates of 1605 trees $\mathrm{ha}^{-1}$ assuming 70\% survival (Burger and Zipper, 2011). 


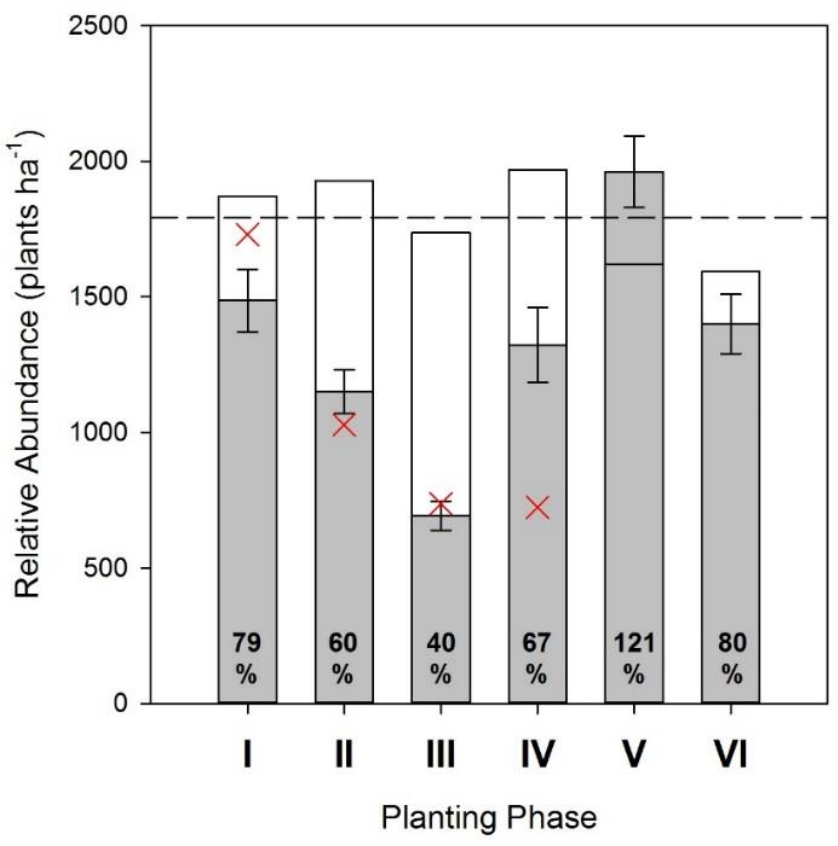

Figure 2. Average relative abundance (gray bars) observed in each Phase relative to number of woody trees and shrubs planted (white bars). Dashed line indicates average trees ha ${ }^{-1}$ planted across all planting phases (1,792 trees $\left.\mathrm{ha}^{-1}\right)$, red crosses represent relative abundance from 2015 inventory, and error bars represent \pm 1 standard error from the mean. Percentage labels on graph indicate percent stocking for each Phase for the 2017 inventory (also represented by the size of gray bars relative to the white bar).

Estimates of relative abundance compared expectedly to our 2015 values by either decreasing as was the case in Phase I or remaining the same (Fig. 2; red crosses). This was not observed for Phase IV, which showed an $82 \%$ increase in total stocking between our two inventories. We speculate this was due to the timing of the sampling. In 2015, Phase IV was inventoried approximately three months following planting to give the newly planted trees as much time as possible to start growing. As a result, the competing vegetation was very high in August with large sections of chest-high goldenrod (Solidago spp. L.) that made locating the newly planted seedlings very difficult, likely contributing to an underestimation of total stocking in 2015 . In contrast, we measured Phase IV in late May and June in 2017 and the planted trees were $70 \%$ larger making them easier to locate.

Across all six phases measured in 2017 we found that among the five conifers that were planted, white pine (Pinus strobus L.) and pitch pine (P. rigida Mill.) had significantly $(p<0.05)$ greater percent stocking relative to the other conifer species planted (Fig. 3; Left). Red spruce (Picea rubens Sarg.) was only planted in Special Planting Zones so the whole-plot data should be 
interpreted with caution (Fig. 3, blue bar). Among the deciduous trees we found that oaks (Quercus spp. L.) and maples (Acer spp. L.) performed significantly ( $<$ 0.05) better then black walnut (Juglans nigra L.) and hickory (Carya spp. Nutt.) species (Fig. 3; Right). Red maple (Acer rubrum L.) and black locust (Robinia pseudoacacia L.) both showed a high degree of natural regeneration (volunteer; Fig. 3; red bar), which has also been noted by others as contributing to increased stocking (Evans et al., 2012).

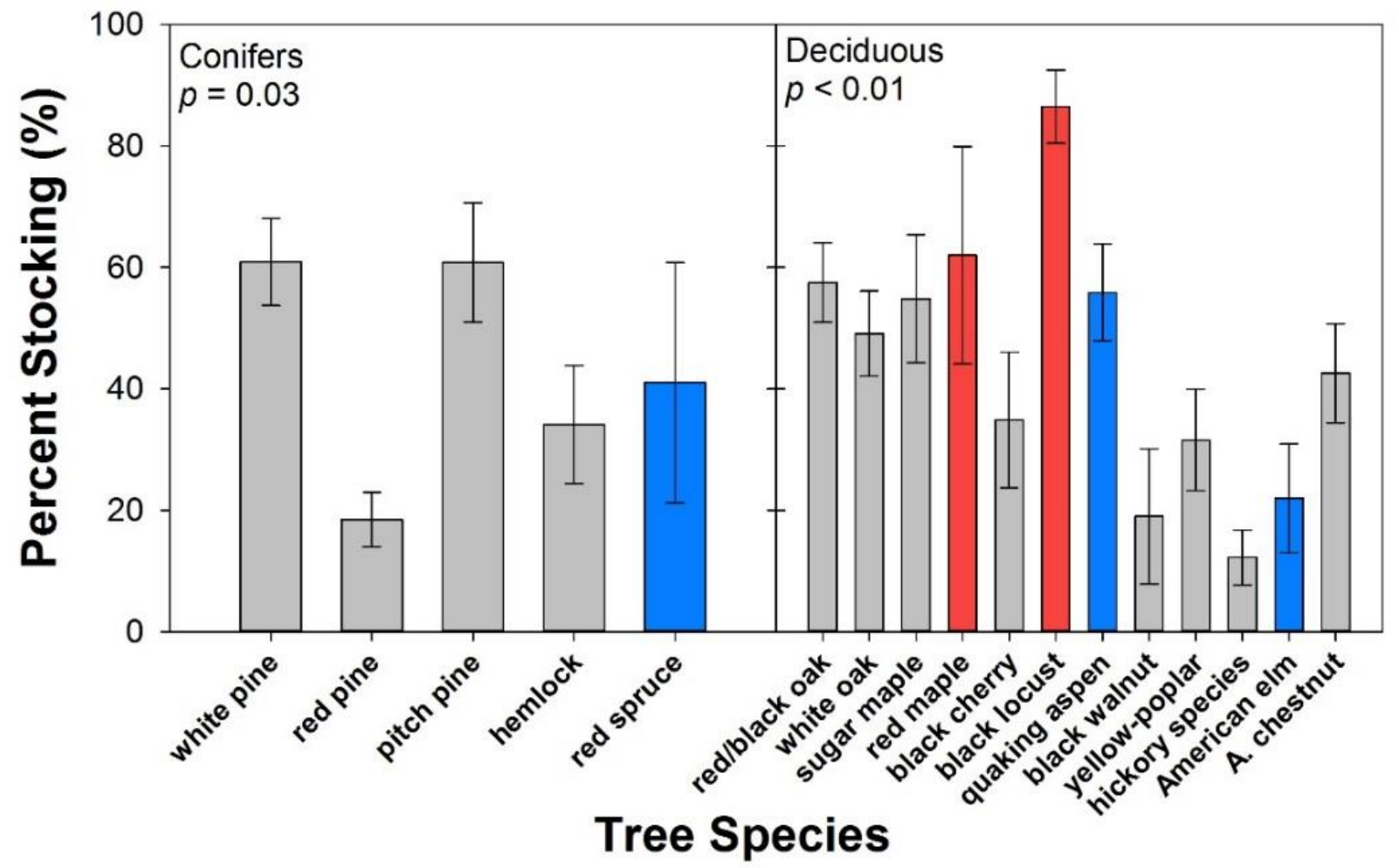

Figure 3. Percent stocking of planted conifer (Left Panel) and deciduous (Right Panel) tree species across all six planting phases. Error bars represent \pm std err from the mean, and probability value was calculated using one-way ANOVA in SAS University. Blue bars indicate plants that were concentrated in Special Planting Zones and may be underestimated; red bars indicate species with high rates of self-seeding.

Total percent stocking in Phase I was 79\% with individual plant groups demonstrating 57, 68, and $156 \%$ survival for coniferous, deciduous tree, and wildlife trees and shrubs, respectively (Table 3). This stocking rate is slightly misleading as there were two species, red maple and hawthorn (Crataegus spp. L.), that had significantly greater observed relative abundance than what was listed in the planting prescription. Both plants showed relatively wide percent dispersion across Phase I, but were also planted in extremely high density within certain plot locations to 
Table 3. Relative abundance, dispersion, percent stocking for (2015 and 2017), and percent change $(\% \Delta)$ of Phase I of The Flight 93 National Monument Reforestation Project five growing seasons after planting (2012).

\begin{tabular}{|c|c|c|c|c|c|c|c|c|}
\hline Phase I: Relative Abundance & Planted & Dispersion & Obs. & \pm & s.e. & 2015 & 2017 & $\% \Delta$ \\
\hline Common name & (plants/ha) & (\% of plots) & \multicolumn{3}{|c|}{ (plants/ha) } & (\%) & $(\%)$ & (\%) \\
\hline white pine & 599 & 93 & 371 & \pm & 46.9 & 63 & 62 & -2 \\
\hline red pine & 91 & 57 & 21 & \pm & 4.9 & 22 & 24 & 7 \\
\hline pitch pine & 65 & 79 & 38 & \pm & 5.1 & 66 & 58 & -13 \\
\hline \multirow{3}{*}{\multicolumn{9}{|c|}{$\begin{array}{l}\text { Virginia pine } \\
\text { hemlock } \\
\text { red spruce }\end{array}$}} \\
\hline & & & & & & & & \\
\hline & & & & & & & & \\
\hline Conifer subtotal & 755 & 93 & 429 & \pm & 50.8 & 59 & 57 & -4 \\
\hline red oak & 156 & 79 & 78 & \pm & 14.5 & 84 & 50 & -41 \\
\hline white oak & 78 & 71 & 49 & \pm & 9.0 & 67 & 63 & -6 \\
\hline black oak & 78 & 82 & 90 & \pm & 15.6 & 44 & 115 & 162 \\
\hline sugar maple & 104 & 68 & 43 & \pm & 8.8 & 45 & 41 & -9 \\
\hline red maple & 78 & 68 & 123 & \pm & 42.4 & 147 & 158 & 7 \\
\hline black cherry & 78 & 79 & 43 & \pm & 7.9 & 87 & 55 & -37 \\
\hline black locust & 78 & 79 & 76 & \pm & 10.9 & 100 & 97 & -3 \\
\hline quaking aspen & 65 & 54 & 40 & \pm & 11.5 & 58 & 62 & 6 \\
\hline \multicolumn{9}{|l|}{ big-tooth aspen } \\
\hline black walnut & 13 & 4 & 1 & \pm & 0.9 & & 7 & \\
\hline blackgum & 52 & 7 & 21 & \pm & 15.9 & 88 & 39 & -55 \\
\hline \multicolumn{9}{|l|}{ yellow-poplar } \\
\hline \multicolumn{9}{|l|}{ hickory species } \\
\hline \multicolumn{9}{|l|}{ American elm } \\
\hline A. chestnut & 74 & 54 & 22 & \pm & 5.0 & 38 & 30 & -21 \\
\hline Deciduous subtotal & 855 & 100 & 586 & \pm & 50.1 & 75 & 68 & -9 \\
\hline \multicolumn{9}{|l|}{ A. hazelnut } \\
\hline dogwood* & 130 & 71 & 96 & \pm & 47.7 & 243 & 73 & -70 \\
\hline A. crabapple & 39 & 32 & 40 & \pm & 15.2 & 64 & 103 & 61 \\
\hline hawthorn & 39 & 93 & 251 & \pm & 45.1 & 513 & 642 & 25 \\
\hline elderberry & 26 & 0 & 0 & \pm & 0.0 & 4 & 0 & -100 \\
\hline staghorn sumac & 13 & 21 & 16 & \pm & 7.6 & 77 & 123 & 60 \\
\hline mountain ash & 13 & 7 & 4 & \pm & 3.6 & 31 & 34 & 11 \\
\hline \multicolumn{9}{|l|}{ ninebark } \\
\hline \multicolumn{9}{|l|}{ scrub oak } \\
\hline \multicolumn{9}{|l|}{ black chokeberry } \\
\hline Wildlife subtotal & 260 & 96 & 407 & \pm & 84.5 & 170 & 156 & -8 \\
\hline bristly locust & & 14 & 4 & \pm & 1.7 & & & \\
\hline sweet cherry & & 54 & 23 & \pm & 5.0 & & & \\
\hline unknown & & 11 & 4 & \pm & 2.9 & & & \\
\hline ash & & 61 & 32 & \pm & 7.1 & & & \\
\hline Other subtotal & 0 & 86 & 63 & \pm & 9.8 & & & \\
\hline GRAND TOTAL & 1,871 & & 1,486 & \pm & 115.6 & 93 & 79 & -15 \\
\hline
\end{tabular}

* Values in bold show greater observed number of plants than what was planted, which are a result of natural seeding, re-sprouting, or planted during reclamation. 
create red stripes as a design feature. This may have led to an over-prediction of these two-plant species; however, we also cannot rule out natural seeding. One contributing factor was that five growing seasons following planting there was substantial natural regeneration of ash (Fraxinus spp. L.), bristly locust (Robinia hispida var. fertilis L.), and sweet cherry [Prunus avium (L.) L.] found throughout the plot (dispersion equal to 61, 54, and 14 percent of plots, respectively; Table 3). We know from personal communication that the original reclamation of the site included plantings for Washington hawthorn, ash, bristly locust, cherry, and arrowwood (Viburnum dentatum L.).

Specifically, among the conifers, white pine and pitch pine had greater than $50 \%$ stocking, whereas red pine (Pinus resinosa Aiton) showed less than 25\% stocking. Among the deciduous trees white oak (Quercus alba L.) showed 63\% stocking. In addition, red (Quercus rubra L.) and black oak (Quercus velutina Lam.) showed high stocking when estimated together, however individually they varied dramatically from their original planting densities, which could be attributed to misidentification of these two trees by the field crew. Sampling of Phase I took place in early June and the leaves were not fully expanded, which may have led to them being misidentified. We also found relatively high stocking among our early successional species such as black cherry (Prunus serotine Ehrh.), black locust, and quaking aspen (Populus tremuloides Michx.). This was likely a result of naturally regenerated individuals that would be difficult to distinguish 5 years after planting. Overall, we observed a $15 \%$ reduction among our total percent stocking between the 2015 and 2017 inventories. This is an expected level of self-selection leaving us with nearly 1,500 woody plants $\mathrm{ha}^{-1}$. The largest difference among woody species was blackgum (Nyssa sylvatica Marsh.) and black cherry which saw the largest percent change among inventory periods (Table 3).

Total percent stocking in Phase II was 60\% with individual plant groups demonstrating 55, 54, and $49 \%$ stocking for coniferous, deciduous tree, and wildlife trees and shrubs, respectively. This estimate included naturally regenerated hawthorns and 90 non-planted woody shrubs (Table 4). This stocking rate was $11 \%$ greater than what was observed in 2015 , however, the conifer and deciduous groups were very similar. For individual species our highest stocking rates were white pine and pitch pine among the conifer species with red pine showing very low rates. Among the deciduous trees we found our greatest stocking (> 80\%) among red maple and black locust, which 
Table 4. Relative abundance, dispersion, percent stocking for (2015 and 2017), and percent change $(\% \Delta)$ from of Phase II of The Flight 93 National Monument Reforestation Project four growing seasons after planting (2013).

\begin{tabular}{|c|c|c|c|c|c|c|c|c|}
\hline Phase II: Relative Abundance & Planted & Dispersion & Obs. & \pm & s.e. & 2015 & 2017 & $\% \Delta$ \\
\hline Common name & (plants/ha) & (\% of plots) & \multicolumn{3}{|c|}{ (plants/ha) } & (\%) & (\%) & $(\%)$ \\
\hline white pine & 747 & 100 & 422 & \pm & 46.9 & 59 & 56 & -4 \\
\hline red pine & 22 & 7 & 2 & \pm & 1.2 & 11 & 8 & -30 \\
\hline pitch pine & 56 & 52 & 43 & \pm & 11.0 & 87 & 77 & -11 \\
\hline \multicolumn{9}{|l|}{ Virginia pine } \\
\hline hemlock & 134 & 52 & 59 & \pm & 14.2 & 40 & 44 & 10 \\
\hline red spruce & & 3 & 1 & \pm & 0.9 & & & \\
\hline Conifer subtotal & 959 & 100 & 526 & \pm & 52.6 & 57 & 55 & -4 \\
\hline red oak & 223 & 97 & 103 & \pm & 10.7 & 46 & 46 & 1 \\
\hline white oak & 67 & 66 & 40 & \pm & 7.2 & 38 & 59 & 56 \\
\hline black oak & 0 & 38 & 18 & \pm & 5.9 & & & \\
\hline sugar maple & 108 & 72 & 56 & \pm & 8.8 & 53 & 52 & -2 \\
\hline red maple & 33 & 52 & 27 & \pm & 6.3 & 38 & 80 & 110 \\
\hline black cherry & 89 & 31 & 13 & \pm & 4.4 & 85 & 14 & -83 \\
\hline black locust & 89 & 62 & 77 & \pm & 24.8 & 41 & 86 & 110 \\
\hline quaking aspen & 67 & 76 & 44 & \pm & 7.3 & 70 & 66 & -6 \\
\hline \multicolumn{9}{|l|}{ big-tooth aspen } \\
\hline black walnut & 22 & 10 & 3 & \pm & 2.0 & 84 & 15 & -82 \\
\hline blackgum & & & & & & & & \\
\hline yellow-poplar & 22 & 24 & 8 & \pm & 2.8 & 30 & 35 & 16 \\
\hline \multicolumn{9}{|l|}{ hickory species } \\
\hline American elm & 17 & 7 & 5 & \pm & 3.6 & 0 & 31 & * \\
\hline A. chestnut & 54 & 79 & 35 & \pm & 6.1 & 71 & 66 & -7 \\
\hline Deciduous subtotal & 792 & 100 & 429 & \pm & 32.5 & 53 & 54 & 2 \\
\hline \multicolumn{9}{|l|}{ A. hazelnut } \\
\hline dogwood* & 88 & 59 & 55 & \pm & 24.9 & 152 & 63 & -59 \\
\hline A. crabapple & 22 & 0 & 0 & \pm & 0.0 & 42 & 0 & -100 \\
\hline hawthorn & 22 & 76 & 43 & \pm & 8.7 & 106 & 193 & 82 \\
\hline elderberry & 22 & 0 & 0 & \pm & 0.0 & 8 & 0 & -100 \\
\hline \multicolumn{9}{|l|}{ staghorn sumac } \\
\hline mountain ash & 0 & 3 & 1 & \pm & 0.9 & & & \\
\hline ninebark & 22 & 52 & 18 & \pm & 3.7 & 38 & 81 & 114 \\
\hline \multirow{2}{*}{\multicolumn{9}{|c|}{$\begin{array}{l}\text { scrub oak } \\
\text { black chokeberry }\end{array}$}} \\
\hline & & & & & & & & \\
\hline Wildlife subtotal & 178 & 100 & 117 & \pm & 29.1 & 43 & 66 & 53 \\
\hline sweet cherry & & 86 & 69 & \pm & 11.0 & & & \\
\hline unknown & & 3 & 4 & \pm & 4.3 & & & \\
\hline ash & & 17 & 5 & \pm & 2.3 & & & \\
\hline Other subtotal & & 90 & 78 & \pm & 13.1 & & & \\
\hline GRAND TOTAL & 1,929 & & 1,151 & \pm & 80.6 & 54 & 60 & 11 \\
\hline
\end{tabular}

* Values in bold show greater observed number of plants than what was planted, which are a result of natural seeding, re-sprouting, or planted during reclamation. 
was likely aided by natural regeneration, and relatively high stocking (>50\%) among white oak, sugar maple, quaking aspen, and American chestnut. Black walnut and American elm (Ulmus americana L.) had the lowest stocking among deciduous trees, however, American elms were planted only within plots that fell within the Special Planting Zones (Fig. 1; red polygons) and should be interpreted with caution. When compared to 2015 inventory data we observed our largest increase in red maple $(+110 \%)$, black locust $(+110 \%)$, hawthorn $(+82 \%)$, and ninebark [Physocarpus opulifolius (L.) Maxim.; +114\%]. Our greatest decrease was observed in red pine $(-30 \%)$ among the conifers and black cherry and blackgum among the deciduous trees (Table 4).

Total stocking in Phase III was $40 \%$ with individual plant groups demonstrating 49, 29, and $15 \%$ stocking for coniferous, deciduous tree, and wildlife trees and shrubs, respectively (Table 5). This rate is significantly lower than what was observed in the other phases (Fig. 2), however, is in close agreement with our 2015 data $(\% \Delta=-3 \%)$. Phase III was the most poorly drained, and therefore, had the highest soil moisture of the six phases. For individual species white pine and black locust represented the greatest percent stocking within their respective plant groups (Table 5). We observed a significant increase in red pine, white oak, and black locust, but many species showed a decrease in stocking since 2015, notably, hemlock and red spruce among the conifers and black cherry, red oak, hickory, and American chestnut among deciduous trees (Table 5).

Total woody plant stocking in Phase IV was 67\%. Individual plant groups had 36, 87, and $107 \%$ stocking for coniferous, deciduous tree, and wildlife trees and shrubs, respectively (Table 6). We found well over $100 \%$ stocking in red maple, black cherry, and black locust, which represent plants that seed very early and likely were naturally regenerated. In addition, we found hawthorn which was planted in the original reclamation effort, but not in 2015, making it likely that they re-sprouted. Our 2017 stocking estimates were $82 \%$ greater than what was estimated in 2015. As previously mentioned, this was likely due to timing of sampling. Summer 2015 inventory took place in August (3 months after planting) when there was a substantial competing vegetation, which likely led to some seedlings not being counted. A few species did not follow this trend, however, such as American chestnut, yellow-poplar (Liriodendron tulipifera L.), and Virginia pine, which all showed a substantial decrease relative to 2015 estimates (Table 6). 
Table 5. Relative abundance, dispersion, percent stocking for (2015 and 2017), and percent change $(\% \Delta)$ from of Phase III of The Flight 93 National Monument Reforestation Project three growing seasons after planting (2014).

\begin{tabular}{|c|c|c|c|c|c|c|c|c|}
\hline Phase III: Relative Abundance & Planted & Dispersion & Obs. & \pm & s.e. & 2015 & 2017 & $\% \Delta$ \\
\hline Common name & (plants/ha) & (\% of plots) & \multicolumn{3}{|c|}{ (plants/ha) } & (\%) & $(\%)$ & $(\%)$ \\
\hline white pine & 697 & 97 & 408 & \pm & 43.9 & 52 & 59 & 13 \\
\hline red pine & 17 & 10 & 3 & \pm & 1.4 & 9 & 15 & 63 \\
\hline pitch pine & 51 & 23 & 17 & \pm & 7.9 & 27 & 33 & 21 \\
\hline Virginia pine & 0 & 3 & 1 & \pm & 0.8 & & & \\
\hline hemlock & 68 & 17 & 8 & \pm & 4.5 & 20 & 12 & -39 \\
\hline red spruce & 68 & 7 & 3 & \pm & 2.6 & 12 & 5 & -59 \\
\hline Conifer subtotal & 901 & 100 & 440 & \pm & 43.8 & 45 & 49 & 9 \\
\hline red oak & 170 & 67 & 42 & \pm & 7.9 & 42 & 25 & -42 \\
\hline white oak & 68 & 43 & 15 & \pm & 3.9 & 9 & 22 & 145 \\
\hline black oak & 0 & 30 & 11 & \pm & 3.5 & & & \\
\hline sugar maple & 51 & 33 & 13 & \pm & 3.5 & 41 & 25 & -40 \\
\hline red maple & 17 & 27 & 8 & \pm & 2.4 & 46 & 44 & -4 \\
\hline black cherry & 85 & 43 & 14 & \pm & 3.3 & 47 & 17 & -65 \\
\hline black locust & 76 & 67 & 58 & \pm & 15.7 & 51 & 76 & 50 \\
\hline quaking aspen & 68 & 53 & 24 & \pm & 5.0 & 46 & 36 & -23 \\
\hline big-tooth aspen & & & & & & & & \\
\hline black walnut & 34 & 3 & 1 & \pm & 0.8 & 2 & 2 & 23 \\
\hline blackgum & & & & & & & & \\
\hline yellow-poplar & 17 & 17 & 4 & \pm & 1.7 & 32 & 25 & -23 \\
\hline hickory species & 42 & 7 & 2 & \pm & 1.2 & 25 & 4 & -84 \\
\hline American elm & 13 & 7 & 2 & \pm & 1.2 & & 13 & * \\
\hline A. chestnut & 76 & 40 & 14 & \pm & 3.9 & 38 & 19 & -51 \\
\hline Deciduous subtotal & 717 & 97 & 207 & \pm & 24.3 & 38 & 29 & -24 \\
\hline A. hazelnut & 8 & 10 & 3 & \pm & 1.4 & 65 & 29 & -55 \\
\hline dogwood* & 67 & 30 & 11 & \pm & 4.4 & 33 & 16 & -51 \\
\hline A. crabapple & 0 & 3 & 1 & \pm & 0.8 & & & \\
\hline hawthorn & 0 & 7 & 2 & \pm & 1.2 & & & \\
\hline elderberry & & & & & & & & \\
\hline staghorn sumac & & & & & & & & \\
\hline mountain ash & 0 & 7 & 2 & \pm & 1.2 & & & \\
\hline ninebark & 0 & 3 & 1 & \pm & 0.8 & & & \\
\hline scrub oak & 42 & 0 & 0 & \pm & 0.0 & 6 & 0 & -100 \\
\hline black chokeberry & & & & & & & & \\
\hline Wildlife subtotal & 119 & 50 & 18 & \pm & 4.8 & 24 & 15 & -36 \\
\hline sweet cherry & & 40 & 18 & \pm & 6.7 & & & \\
\hline unknown & & 10 & 3 & \pm & 1.4 & & & \\
\hline ash & & 13 & 7 & \pm & 4.3 & & & \\
\hline Other subtotal & & 57 & 28 & \pm & 7.4 & & & \\
\hline GRAND TOTAL & 1,737 & & 693 & \pm & 54.0 & 41 & 40 & -3 \\
\hline
\end{tabular}

* Values in bold show greater observed number of plants than what was planted, which are a result of natural seeding, re-sprouting, or planted during reclamation. 
Table 6. Relative abundance, dispersion, percent stocking for (2015 and 2017), and percent change $(\% \Delta)$ from of Phase IV of The Flight 93 National Monument Reforestation Project two growing seasons after planting (2015).

\begin{tabular}{|c|c|c|c|c|c|c|c|c|}
\hline \multirow{2}{*}{$\begin{array}{l}\text { Phase IV: Relative Abundance } \\
\text { Common name }\end{array}$} & Planted & Dispersion & Obs. & \pm & s.e. & 2015 & 2017 & $\% \Delta$ \\
\hline & (plants/ha) & (\% of plots) & \multicolumn{3}{|c|}{ (plants/ha) } & $(\%)$ & $(\%)$ & (\%) \\
\hline white pine & 809 & 87 & 300 & \pm & 39.3 & 36 & 37 & 3 \\
\hline red pine & 18 & 20 & 5 & \pm & 1.9 & 0 & 28 & * \\
\hline pitch pine & 0 & 13 & 5 & \pm & 2.5 & & & \\
\hline Virginia pine & 31 & 13 & 9 & \pm & 4.9 & 81 & 29 & -64 \\
\hline hemlock & 63 & 27 & 10 & \pm & 3.5 & 24 & 16 & -33 \\
\hline red spruce & 63 & 3 & 28 & \pm & 28.3 & 34 & 45 & 33 \\
\hline Conifer subtotal & 984 & 90 & 358 & \pm & 43.1 & 36 & 36 & 1 \\
\hline red oak & 215 & 90 & 116 & \pm & 16.3 & 42 & 54 & 28 \\
\hline white oak & 98 & 83 & 63 & \pm & 9.7 & 46 & 64 & 40 \\
\hline black oak & & & & & & - & & \\
\hline sugar maple & 63 & 67 & 48 & \pm & 8.3 & 41 & 77 & 88 \\
\hline red maple & 18 & 47 & 61 & \pm & 23.9 & 42 & 340 & 710 \\
\hline black cherry & 45 & 87 & 118 & \pm & 23.9 & 72 & 263 & 265 \\
\hline black locust & 81 & 73 & 244 & \pm & 80.9 & 23 & 303 & 1219 \\
\hline quaking aspen & 81 & 13 & 53 & \pm & 32.6 & 51 & 66 & 30 \\
\hline big-tooth aspen & & & & & & & & \\
\hline black walnut & 36 & 37 & 18 & \pm & 5.7 & 60 & 51 & -15 \\
\hline blackgum & 0 & 3 & 1 & \pm & 0.8 & & & \\
\hline yellow-poplar & 18 & 10 & 3 & \pm & 1.4 & 32 & 14 & -56 \\
\hline hickory species & 98 & 17 & 5 & \pm & 2.2 & 3 & 5 & 69 \\
\hline American elm & & & & & & & & \\
\hline A. chestnut & 134 & 70 & 38 & \pm & 6.3 & 42 & 28 & -33 \\
\hline Deciduous subtotal & 886 & 100 & 768 & \pm & 96.2 & 39 & 87 & 122 \\
\hline A. hazelnut & & & & & & & & \\
\hline dogwood* & 63 & 47 & 72 & \pm & 19.7 & 18 & 114 & 532 \\
\hline A. crabapple & 18 & 10 & 3 & \pm & 1.4 & 5 & 14 & 180 \\
\hline hawthorn & 0 & 7 & 28 & \pm & 26.7 & & & \\
\hline elderberry & & & & & & & & \\
\hline staghorn sumac & & & & & & & & \\
\hline mountain ash & 18 & 10 & 3 & \pm & 2.0 & 19 & 19 & -2 \\
\hline ninebark & & & & & & & & \\
\hline scrub oak & & & & & & & & \\
\hline black chokeberry & & & & & & & & \\
\hline Wildlife subtotal & 98 & 53 & 105 & \pm & 38.2 & 11 & 107 & 870 \\
\hline alder & & 13 & 5 & \pm & 2.5 & & & \\
\hline honeysuckel & & 3 & 1 & \pm & 0.8 & & & \\
\hline serviceberry & & 7 & 6 & \pm & 5.0 & & & \\
\hline sweet cherry & & 17 & 14 & \pm & 8.6 & & & \\
\hline unknown & & 3 & 1 & \pm & 0.8 & & & \\
\hline viburnum & & 7 & 13 & \pm & 12.5 & & & \\
\hline ash & & 60 & 53 & \pm & 14.3 & & & \\
\hline Other subtotal & & 80 & 93 & \pm & 27.0 & & & \\
\hline GRAND TOTAL & 1,968 & & 1,323 & \pm & 137.7 & 37 & 67 & 82 \\
\hline
\end{tabular}

* Values in bold show greater observed number of plants than what was planted, which are a result of natural seeding, re-sprouting, or planted during reclamation.

Similar to what we observed in Phase IV, we found that red maple, black cherry, and black locust had more individuals than was planted in Phase V. One year after planting (2016), the 
percent stocking well exceeded $100 \%$ for Phase V (121\%) with all but the hickories and the wildlife shrubs exceeding $50 \%$ survival. We observed some competing woody vegetation that moved into the plots with alder (Alnus spp. Mill.) and serviceberry (Amelanchier spp. Medik.) likely invading from the edges and Scots pine (Pinus sylvestris L.) leftover from previous plantings (Table 7). Phase VI had an overall percent stocking just three months after planting (May 2017) of $80 \%$ (Table 8). We found more black locust and hawthorn than was planted, which was a result of re-sprouting from existing vegetation prior to site preparation. The greatest stocking was observed in big-tooth aspen (Populus grandidentata Michx.), white pine, black chokeberry [Photinia melanocarpa (Michx.) K.R. Robertson \& Phipps], and dogwood spp. with hickory species showing the least stocking (Table 8).

\section{Objective 2. Plant Growth and Deer Browse}

Plant Height Summary. Average plant height increased, expectedly, with time since planting among our six Phases (Fig. 4; Left Panel) with a slight decrease in phase III, which also showed the lowest stocking. Greatest plant height was observed among conifer species with pitch pine outperforming all other planted conifer species immediately after planting and white pine surpassing after 3 years since planting (Fig. 4; Center Panel, Red Line). White pine generally has a two-year period of little height growth followed by rapid growth making early competition control vital to its establishment success (Dickerson, 2002). Deciduous plants showed less overall height growth relative to planted conifers, however, we consistently observed black locust and aspen showing greatest height (Fig. 4; Right Panel). 
Table 7. Relative abundance, dispersion, and percent stocking for 2017 of Phase V of The Flight 93 National Monument Reforestation Project one growing seasons after planting (2016).

\begin{tabular}{|c|c|c|c|c|c|c|c|c|}
\hline \multirow{2}{*}{$\begin{array}{l}\text { Phase V: Relative Abundance } \\
\begin{array}{l}\text { Common name }\end{array}\end{array}$} & \multirow{2}{*}{$\begin{array}{c}\text { Planted } \\
\text { (plants/ha) }\end{array}$} & \multirow{2}{*}{$\begin{array}{c}\text { Dispersion } \\
\text { (\% of plots) }\end{array}$} & \multicolumn{3}{|c|}{ Obs. \pm s.e. } & \multirow{2}{*}{$\begin{array}{c}2015 \\
(\%)\end{array}$} & \multirow{2}{*}{$\begin{array}{c}2017 \\
(\%)\end{array}$} & \multirow{2}{*}{$\begin{array}{l}\% \Delta \\
\%)\end{array}$} \\
\hline & & & \multicolumn{3}{|c|}{ (plants/ha) } & & & \\
\hline white pine & 624 & 100 & 572 & \pm & 51.8 & & 92 & \\
\hline red pine & 0 & 3 & 1 & \pm & 0.9 & & - & \\
\hline pitch pine & 97 & 93 & 85 & \pm & 13.8 & & 88 & \\
\hline Virginia pine & & & & & & & & \\
\hline hemlock & 49 & 55 & 32 & \pm & 7.0 & & 65 & \\
\hline red spruce & 39 & 66 & 28 & \pm & 5.1 & & 73 & \\
\hline Conifer subtotal & 809 & 100 & 718 & $\underline{ \pm}$ & 56.7 & & 89 & \\
\hline red oak & 166 & 93 & 127 & \pm & 18.0 & & 76 & \\
\hline white oak & 49 & 52 & 25 & \pm & 5.5 & & 51 & \\
\hline black oak & & & & & & & & \\
\hline sugar maple & 29 & 55 & 23 & \pm & 5.1 & & 80 & \\
\hline red maple & 3 & 90 & 95 & \pm & 16.0 & & 2780 & \\
\hline black cherry & 68 & 100 & 207 & \pm & 26.6 & & 303 & \\
\hline black locust & 49 & 83 & 129 & \pm & 46.8 & & 265 & \\
\hline quaking aspen & 49 & 76 & 38 & \pm & 6.6 & & 78 & \\
\hline big-tooth aspen & & & & & & & & \\
\hline black walnut & 0 & 24 & 8 & \pm & 2.8 & & - & \\
\hline blackgum & & & & & & & & \\
\hline yellow-poplar & 19 & 34 & 10 & \pm & 2.9 & & 53 & \\
\hline hickory species & 78 & 48 & 16 & \pm & 3.8 & & 21 & \\
\hline American elm & & & & & & & & \\
\hline A. chestnut & 146 & 76 & 94 & \pm & 18.6 & & 64 & \\
\hline Deciduous subtotal & 656 & 100 & 772 & \pm & 71.7 & & 118 & \\
\hline A. hazelnut & & & & & & & & \\
\hline dogwood* & 49 & 48 & 18 & \pm & 4.1 & & 37 & \\
\hline A. crabapple & 0 & 7 & 3 & \pm & 1.9 & & - & \\
\hline hawthorn & 0 & 34 & 24 & \pm & 8.5 & & - & \\
\hline elderberry & 49 & 3 & 1 & \pm & 0.9 & & 2 & \\
\hline $\begin{array}{l}\text { staghorn sumac } \\
\text { mountain ash }\end{array}$ & & & & & & & & \\
\hline ninebark & 58 & 0 & 0 & \pm & 0.0 & & 0 & \\
\hline scrub oak & & & & & & & & \\
\hline black chokeberry & & & & & & & & \\
\hline Wildlife subtotal & 156 & 66 & 46 & \pm & 12.0 & & 29 & \\
\hline autumn-olive & & 3 & 1 & \pm & 0.9 & & & \\
\hline alder & & 45 & 97 & \pm & 33.1 & & & \\
\hline bristly locust & & 14 & 3 & \pm & 1.6 & & & \\
\hline Scots pine & & 31 & 57 & \pm & 24.9 & & & \\
\hline serviceberry & & 97 & 232 & \pm & 36.9 & & & \\
\hline unknown & & 17 & 5 & \pm & 2.3 & & & \\
\hline viburnum & & 24 & 16 & \pm & 6.2 & & & \\
\hline ash & & 24 & 14 & \pm & 6.6 & & & \\
\hline Other subtotal & 0 & 100 & 425 & \pm & 63.9 & & & \\
\hline GRAND TOTAL & 1,621 & & 1,961 & \pm & 131.2 & & 121 & \\
\hline
\end{tabular}

* Values in bold show greater observed number of plants than what was planted, which are a result of natural seeding, re-sprouting, or planted during reclamation. 
Table 8. Relative abundance, dispersion, and percent stocking for 2017 of Phase VI of The Flight 93 National Monument Reforestation Project less than one growing seasons after planting (2017).

\begin{tabular}{|c|c|c|c|c|c|c|c|c|}
\hline Phase VI: Relative Abundance & Planted & Dispersion & Obs. & \pm & s.e. & 2015 & 2017 & $\% \Delta$ \\
\hline Common name & (plants/ha) & (\% of plots) & (plar & nts/ & ha) & (\%) & (\%) & (\%) \\
\hline white pine & 659 & 94 & 395 & \pm & 31.4 & & 60 & \\
\hline red pine & & & & & & & & \\
\hline pitch pine & 82 & 27 & 40 & \pm & 9.7 & & 49 & \\
\hline Virginia pine & & & & & & & & \\
\hline hemlock & 82 & 20 & 27 & \pm & 7.5 & & 33 & \\
\hline red spruce & 0 & 3 & 3 & \pm & 1.8 & & - & \\
\hline Conifer subtotal & 824 & 97 & 465 & \pm & 35.6 & & 56 & \\
\hline red oak & 165 & 57 & 83 & \pm & 12.0 & & 50 & \\
\hline white oak & 82 & 26 & 29 & \pm & 6.3 & & 35 & \\
\hline black oak & 0 & 11 & 12 & \pm & 4.1 & & - & \\
\hline sugar maple & & & & & & & & \\
\hline red maple & 0 & 1 & 1 & \pm & 1.3 & & - & \\
\hline black cherry & 82 & 37 & 44 & \pm & 8.2 & & 54 & \\
\hline black locust & 41 & 27 & 121 & \pm & 48.2 & & 293 & \\
\hline quaking aspen & 27 & 9 & 8 & \pm & 3.1 & & 28 & \\
\hline big-tooth aspen & 27 & 19 & 22 & \pm & 6.3 & & 80 & \\
\hline black walnut & 0 & 3 & 3 & \pm & 1.8 & & - & \\
\hline blackgum & & & & & & & & \\
\hline yellow-poplar & & & & & & & & \\
\hline hickory species & 41 & 9 & 8 & \pm & 3.1 & & 19 & \\
\hline American elm & & & & & & & & \\
\hline A. chestnut & 137 & 41 & 66 & \pm & 12.1 & & 48 & \\
\hline Deciduous subtotal & 604 & 96 & 396 & \pm & 58.2 & & 66 & \\
\hline A. hazelnut & & & & & & & & \\
\hline dogwood* & 55 & 14 & 39 & \pm & 17.5 & & 71 & \\
\hline A. crabapple & 55 & 4 & 14 & \pm & 9.9 & & 26 & \\
\hline hawthorn & 0 & 56 & 251 & \pm & 52.1 & & - & \\
\hline elderberry & & & & & & & & \\
\hline staghorn sumac & & & & & & & & \\
\hline mountain ash & & & & & & & & \\
\hline ninebark & 0 & 3 & 4 & \pm & 2.9 & & - & \\
\hline scrub oak & & & & & & & & \\
\hline black chokeberry & 55 & 31 & 39 & \pm & 12.4 & & 71 & \\
\hline Wildlife subtotal & 165 & 69 & 347 & \pm & 63.8 & & 210 & \\
\hline sweet cherry & & 44 & 57 & \pm & 8.9 & & & \\
\hline unknown & & 4 & 5 & \pm & 3.1 & & & \\
\hline ash & & 3 & 3 & \pm & 1.8 & & & \\
\hline Other subtotal & & 49 & 65 & \pm & 9.5 & & & \\
\hline GRAND TOTAL & 1,593 & & 1,400 & \pm & 110.1 & & 80 & \\
\hline
\end{tabular}

* Values in bold show greater observed number of plants than what was planted, which are a result of natural seeding, re-sprouting, or planted during reclamation. 


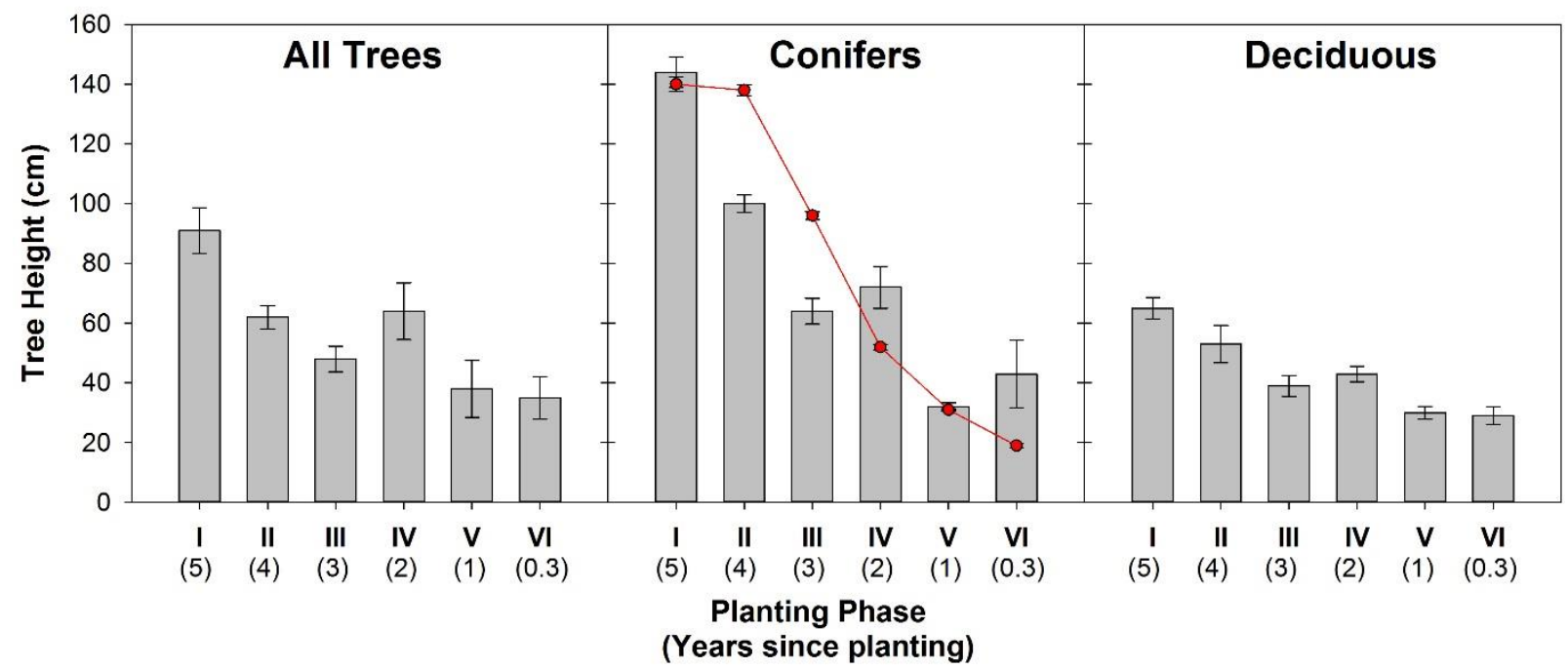

Figure 4. Average height for all planted trees (Left Panel), conifer trees only (Center Panel), and deciduous trees only (Right Panel). Red points and line show average height of white pine only and error bars represent \pm 1 standard error from the mean.

Growth Rate. For all conifer and deciduous species that were planted we calculated a growth rate

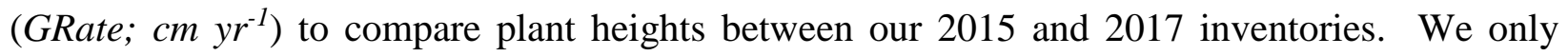
included tree species that were represented in both inventories and found that GRate was greatest in white and pitch pine among the conifers (Fig. 5; Blue Bars) with the exception of Virginia pine which was only planted in Phase IV (Fig. 5; Gray Bar). Hemlock and red spruce when planted showed slow but steady growth between 2015 and 2017, which is consistent with later successional species. Overall, growth was extremely suppressed in the deciduous species that were planted with the exception of black locust, which consistently showed the highest GRate in the four phases measured (Fig. 5; Red Bars). These growth rates are quite low in comparison to other reclamation studies (Michels et al., 2007; Skousen et al., 2009). 


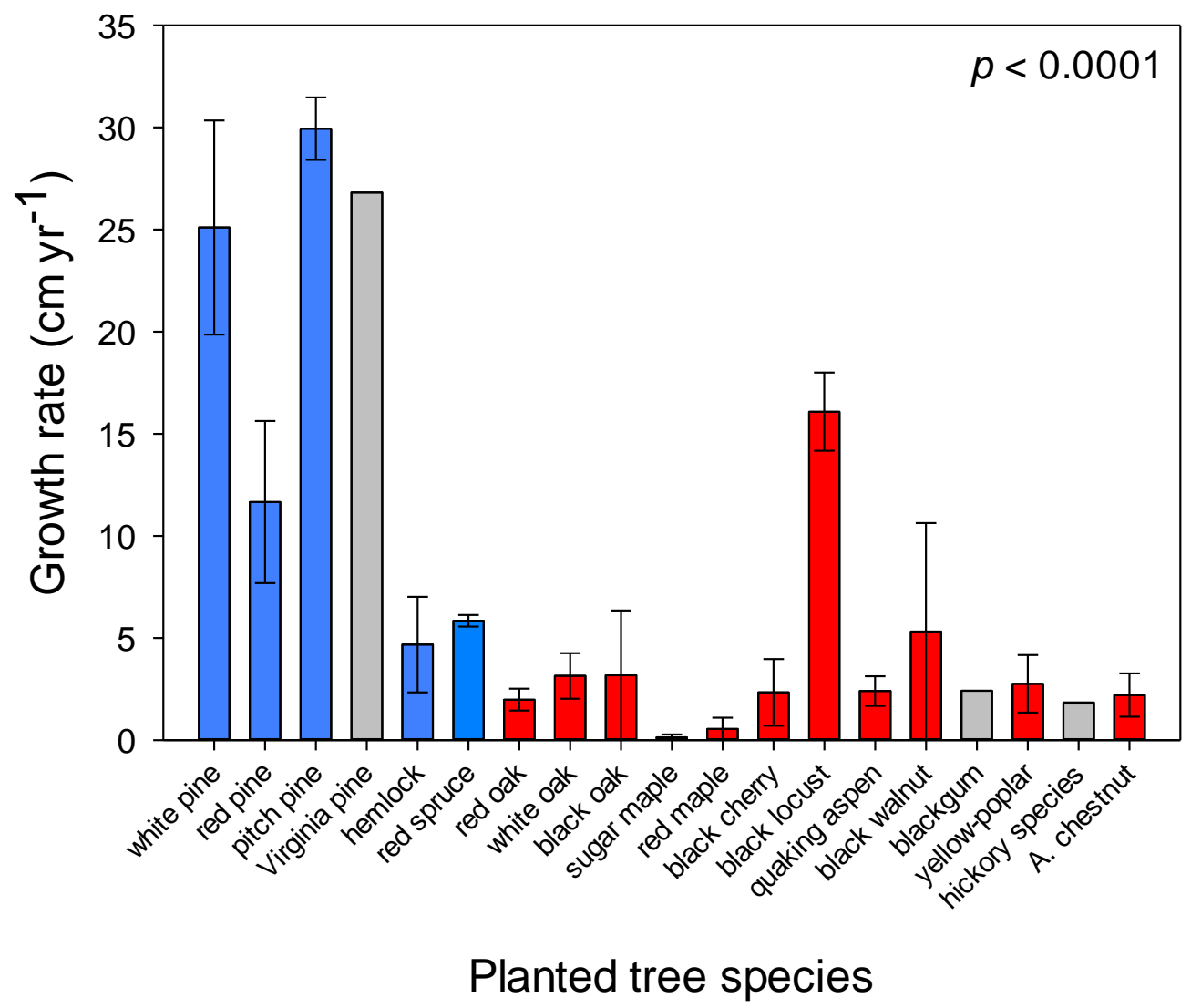

Figure 5. Average growth rate for tree species measured in both 2015 and 2017 inventories. Blue, gray, and red bars represent conifer and deciduous species, respectively, and gray bars indicate species only planted in one of the four planting phases. Data were analyzed across planting phases I thru IV using one-way ANOVA, error bars represent \pm 1 standard error from the mean, and all analyses were performed using SAS University.

Deer Browse. Deer browse was extremely low across the site with $88 \%$ of all plants sampled showing no sign of browse and 10\% showing only slight (Data not shown). Overall, the conifer group showed the least percentage of planted trees to contain some level of deer browse relative to the deciduous and wildlife shrubs. Phase IV showed the highest percentage (9\%) of deer browse among the conifers with hemlock being the conifer species most often impacted. Among the planted deciduous trees, we observed black locust, quaking aspen, and black walnut to show the highest levels of deer browse with black walnut showing $100 \%$ of plants showing some browse in Phases I and III. Burney and Jacobs (2018) postulated that species selection may be the most cost effective way of managing for deer browse. The wildlife tree and shrubs are more difficult to identify trends across the planting phases due to the large variation in plant selection across the 
planting phases. The exceptions are the dogwood species which did show up in all six Phases. We observed the highest rate of deer browse in Phase I among the dogwood species. We attribute our relatively low rates of deer browse to advanced competing vegetation which provided protection of the growing seedlings from deer browse (Skousen et al., 2009), however, our low growth rates suggest our plants are being suppressed.

\section{Objective 3. Competing Vegetation}

The Flight 93 reforestation planting phases were established over the last six years, which provides an opportunity to observe how the site will progress. Overall, the site is following the expected seral stages of "old-field" succession (Barnes et al., 1998) with some important differences that were detailed by Bauman et. al. (2015). First, these fields were planted with fastgrowing and often invasive grass mixtures to prevent erosion when the site was originally reclaimed (mid 1990s). Over the years these species have become well established and developed extensive seedbanks. Second, this site was hand planted with woody trees and shrubs at an average density of nearly 1,800 woody trees and shrubs per hectare. All of these phases were dominated by bare soil at the time of planting. During site preparation the phases were ripped in both directions to prepare the site for planting. This also exposed the mineral soils across most of the planting phase. We observed that bare soil decreased rapidly during the first and second growing season after planting (Fig. 6). This continued to decrease until approximately $10 \%$ of the available space remained bare soil. The ripping left deep trenches with steep sides that continue to erode, which is likely why there is bare soil even five years after replanting. Grass, sedge, and herbaceous dicots dominate the sites with both categories occupying approximately $50 \%$ combined within months after planting to nearly $85 \%$ years later (Fig. 6). We see a slight increase in woody vegetation and Rubus spp. over time and we would expect this trend to continue over time as described by Burger and Zipper (2011).

We observed available bare soil (orange bars) decreasing as we move from Phase VI (0.3 years after planting) to Phase I (5 years after planting) and herbaceous vegetation (yellow bars) increasing (Fig. 7). Rubus and volunteer woody species have become increasingly more prevalent as we move towards the older planting phases, however, we do see Rubus spp. decreasing relative to 2015 estimates (red dots) as herbaceous vegetation increases (yellow bars; Fig. 7). 


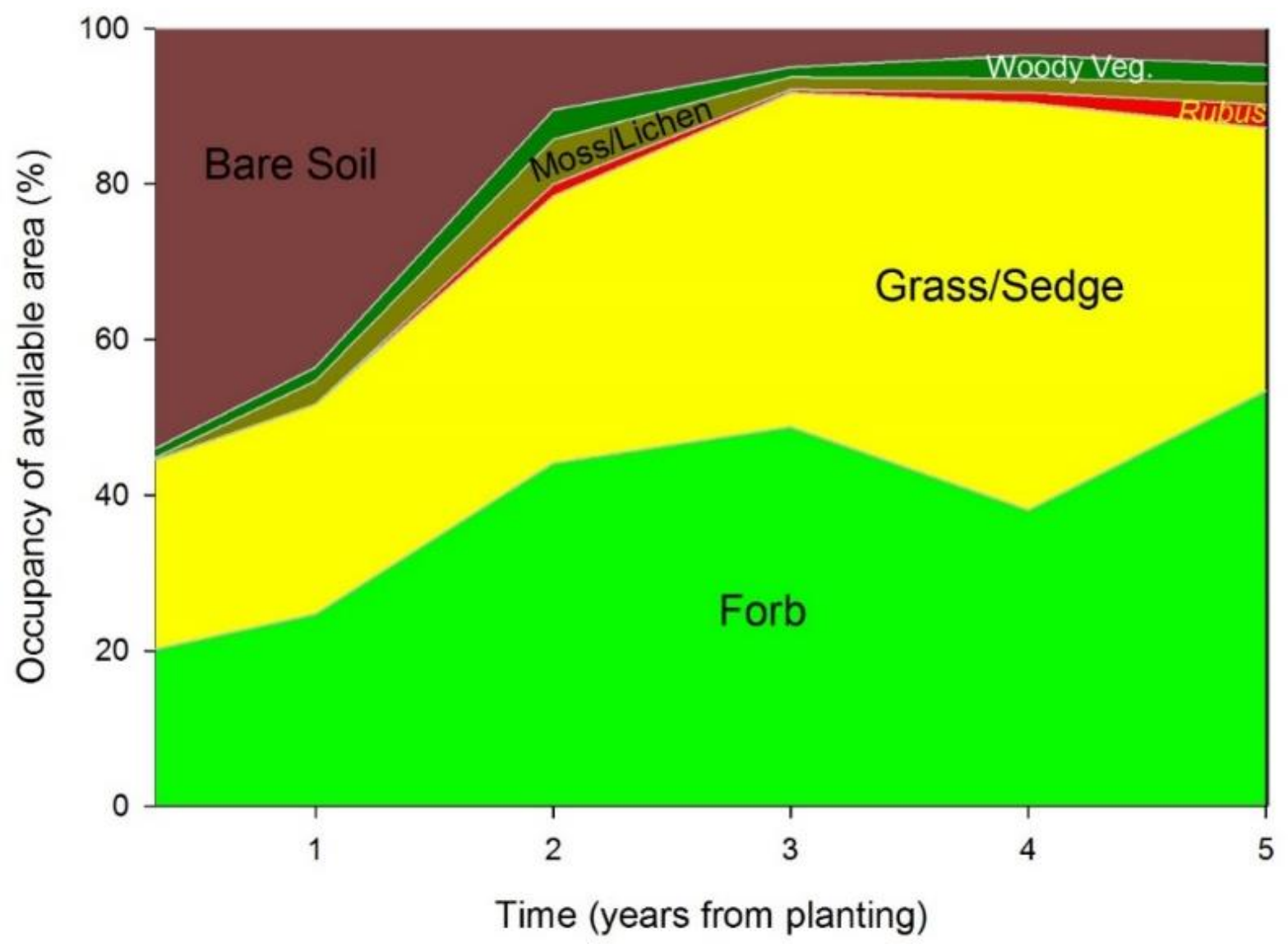

Figure 6. Percent available area occupied by bare soil, forb (herbaceous dicot), grass/sedge, woody vegetation, Rubus, or moss/lichens. Percent occupancy data has been prorated to account of area which is unavailable for plant growth, such as rocky areas or standing water.

\section{Conclusions}

This report provides a comparison of growth, deer browse, and survival for the 34 native species planted at the Flight 93 National Memorial. Total percent stocking across all six planting Phases was $74.5 \%$ ranging from $40-121 \%$ within individual Phases with natural regeneration driving stocking levels above $100 \%$ in one of the planting phases. Phase III had the lowest stocking value relative to the other five phases. Phase III is also the wettest of the six phases and we speculate this contributed to the low stocking levels. In our study natural regeneration is a significant contributor to overall percent stocking, which has been observed by others (Evans et al., 2012). Planting rates and current stocking rates are above the 1605 and 988 tree $^{-1}$ recommended for levels of planting and stocking, respectively for noncommercial forest land (Burger and Zipper, 2011). Greatest plant growth was observed in the conifer species with white pine and pitch pine driving this pattern. Among the deciduous trees we observed the greatest 
growth among the early successional species such as quaking aspen and black locust, however overall, growth rates are comparatively low for deciduous tree species. Competing vegetation across all six planting phases was dominated by grasses, sedges, and herbaceous dicots and constitutes the largest limitation to woody plant establishment. Site preparation involved deep ripping, however, herbicide application was not part of the site preparation prescription. We believe competing vegetation has had an impact of our observed rate of deer browse. Overall, $88 \%$ of all plants showed no sign of deer browse, however, this rate is expected to increase as the plants emerge above the competing vegetation.

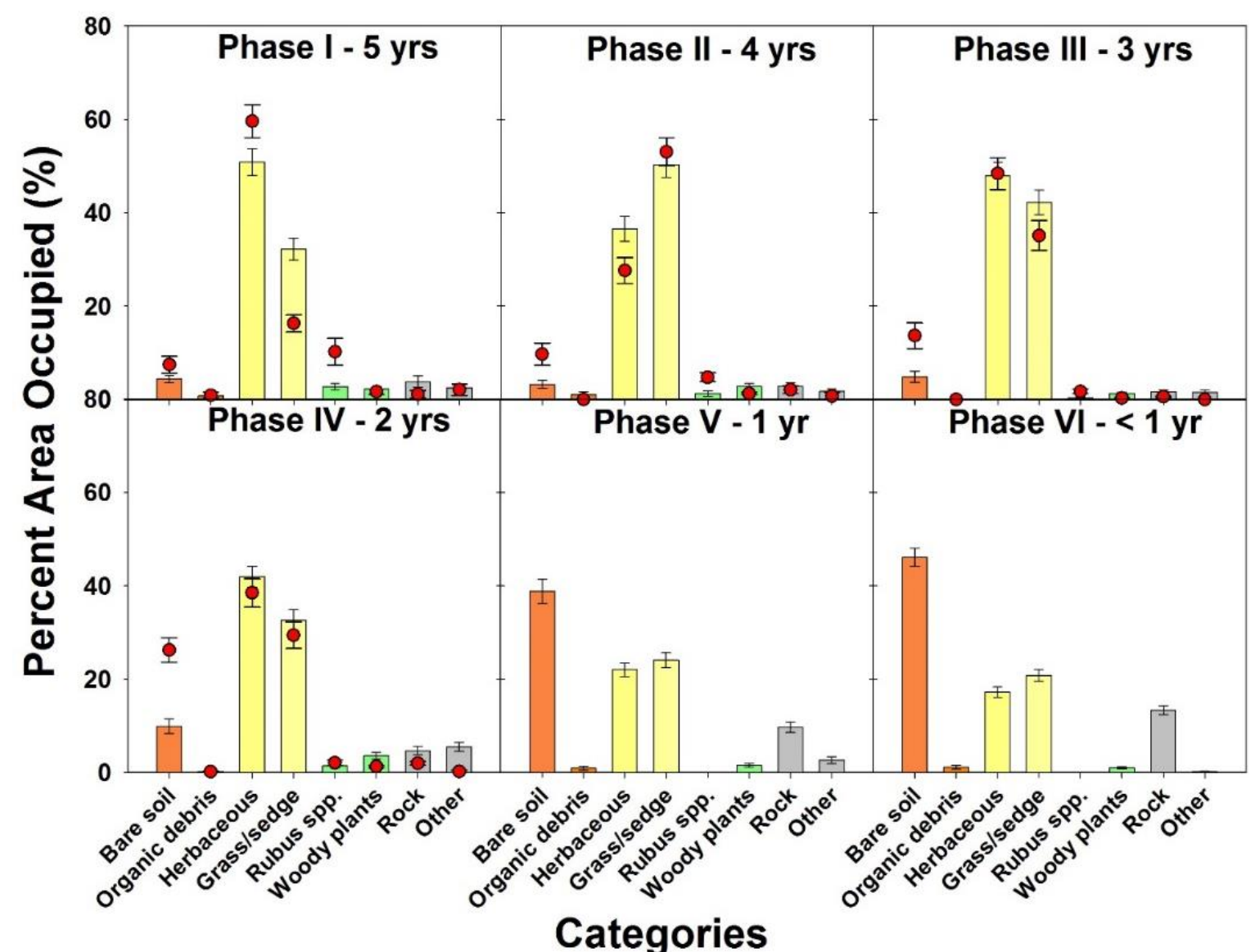

Figure 7. Percent area occupied for each of the six planting phases. Bars show average area occupied for each category with colors representing potential or available growing space (orange), herbaceous vegetation (yellow), woody vegetation (green), unavailable growing space (gray). Error bars represent \pm 1 standard error from the mean. Red dots and error bars represent data from the 2015 inventory ( 2 years ago). 


\section{Acknowledgements}

This work was made possible by funding from: 1. Green Forests Work (http://www.greenforestswork.org/ ) through a grant from the National Fish and Wildlife Foundation and the US Department of the Interior entitled: Flight 93 National Memorial Youth Initiative Mined-Land Reforestation Project; 2. The National Park Foundation (http://www.nationalparks.org/); and 3. Indiana University of Pennsylvania, Department of Biology.

Thanks to the National Park Service for access to the Flight 93 National Memorial for data collection (Collection Permit \#: FLNI-2017-SCI-0001 and FLNI-2015-SCI-0003 for the 2017 and 2015 inventories, respectively). Special thanks to Leroy Renninger and MaryEllen Snyder from the National Park Service for providing access and onsite assistance throughout the data collection. Thanks to Shannon Johns, Caleb Brady, Aaron Wolfe, Cassandra Krul, and Ian Forte for their exceptional work in the field collecting data throughout the summers of 2015 and 2017. Also, thanks to Kathryn Coates for her assistance in the field. This work would not have been completed without their hard work. Finally, thanks to Wesley Palmer and Wilson Hood for their GIS assistance throughout this project.

\section{Literature Cited}

ARRI 2012 Statement of Mutual Intent. Appalachian Regional Reforestation Initiative. https://arri.osmre.gov/SMI/ARRI_SMI_revised.02.2007.pdf

Barnes B.V, D.R. Zak, S.R. Denton, and S.H. Spurr 1998 Forest Ecology. John Wiley \& Sons, Inc. New York

Bauman J.M, C. Cochran, J. Chapman, and K. Gilland. 2015 Plant community development following restoration treatments on a legacy reclaimed mine site. Ecological Engineering 83: 521-528 https://doi.org/10.1016/j.ecoleng.2015.06.023

Burger J.A, and C.E. Zipper. 2011 How to Restore Forests on Surface-Mined Land. Powell River Project Reclamation Guidelines for Surface Mined Land. Virginia Tech, Virginia Cooperative Extension, pp 1-20

Burger J.A., C.E. Zipper, P.N. Angel, N. Hall, J.G. Skousen, C,B. Barton, and S.E. Eggerud 2017 Chapter 10: Establishing native trees on legacy surface mines In: Adams MB (ed) The Forestry Reclamation Approach: guide to successful reforestation of mined lands. U.S. Department of Agriculture, Forest Service, Northern Research Station, pp 10.11 - 10.12

Burney O.T., and D.F. Jacobs 2018 Species selection - A fundamental silvicultural tool to promote forest regeneration under high animal browsing pressure. Forest Ecology and Management 408: 67-74 https://doi.org/10.1016/j.foreco.2017.10.037 
Dickerson J., 2002 United States Department of Agriculture, Natural Resources Conservation Service - Plant Fact Sheet.

Evans D.M., C.E. Zipper, J.A.Burger, B.D. Strahm, and A.M. Villamagnac 2012 Reforestation practice for enhancement of ecosystem services on a compacted surface mine: Path toward $\begin{array}{lllll}\text { ecosystem } & \text { recovery. } & \text { Ecological } & \text { Engineering }\end{array}$ https://doi.org/10.1016/j.ecoleng.2012.12.065

Michels A., C.B. Barton, T. Cushing, P.N. Angel, R. Sweigard, and Graves 2007 Evaluation of Low Spoil Compaction Techniques for Hardwood Forest Establishment on an Eastern Kentucky Surface Mine. In: Barnhisel RI (ed) Proceedings of 2007 National Meeting of the American Society of Mining and Reclamation, Gillette WY, June 2-7, 2007. Published by ASMR, 3134 Montavesta Rd., Lexington, KY 40502, pp 492-503 https://doi.org/10.21000/JASMR07010492

NPS 2013 Flight 93 National Memorial, Cell Phone Tour Script. National Park Service, U.S. Department of the Interior

Skousen J, J. Gorman, E. Pena-Yewtukhiw, J. King, J. Stewart, P. Emerson, and C. DeLong 2009 Hardwood Tree Survival in Heavy Ground Cover on Reclaimed Land in West Virginia: Mowing and Ripping Effects All rights reserved. No part of this periodical may be reproduced or transmitted in any form or by any means, electronic or mechanical, including photocopying, recording, or any information storage and retrieval system, without permission in writing from the publisher. J. Environ. Qual. 38: 1400-1409 https://doi.org/10.2134/jeq2008.0297

U.S.Climate_Data 2015a Ohiopyle Pennsylvania, chalk hill 2 ene, Longitude: -79.583, Latitude: 39.8508. Version 2.2 beta. U.S. Climate Data

U.S.Climate_Data 2015b Stoystown Pennsylvania Longitude: -78.95, Latitude: 40.1. Version 2.2 beta. U.S. Climate Data 